\title{
Karakterisasi dan Efektifitas Cangkang Bekicot (Achatina fulica) Sebagai Biosorben dalam Menyerap Logam Berat Fe pada Air Limbah Sintetik
}

\author{
Deasy Amanda Valentine ${ }^{1 *}$, Azhar $^{2}$, Mitha Putri Paradila ${ }^{3}$ \\ ${ }^{1,2,3}$ Prodi Kesehatan Lingkungan STIKes Bustanul Ulum Langsa, Aceh \\ *Koresponden email: deasya85@gmail.com
}

Diterima: 25 September 2021

Disetujui: 4 November 2021

\begin{abstract}
The metal remittance in this review is Fe metal, since Fe is one of the metals that is generally contained in water. Whenever devoured water containing Fe that surpasses the limit, it will be awful for wellbeing. The purpose for this research was to portray the biosorbent of snail shell powder and to test the presentation of the biosorbent in the retention of substantial metal iron (Fe). From the aftereffects of the FTIR test, it is assessed that there has been an adjustment of chitin to chitosan. The chitosan spectra acquired showed the presence of a retention band at a wave number of $3066 \mathrm{~cm}-1$ because of the extending vibration of the Goodness bunch. while for the portrayal utilizing SEM, the molecule size of the biosorbent has different sizes, to be specific with a size scope of $2.16-3.44 \mathrm{~m}$ to $2.54-12.12 \mu \mathrm{m}$. The development of a coral-like surface is the most definitive factor in the partition of the weighty metal retention interaction of $\mathrm{Fe}$. The computation of the viability esteem showed that the adequacy of snail shell powder in engrossing $10 \mathrm{ppm}$ Fe metal was at a mass of $20 \mathrm{~g}$ with a mixing season of 30 minutes, which was $99.2 \%$.
\end{abstract}

Keywords: biosorbent, snail, FTIR, SEM, Fe

\begin{abstract}
Abstrak
Penyisihan logam dalam penelitian ini adalah logam Fe, karena Fe merupakan salah satu logam yang umumnya terkandung dalam air. Setiap kali meminum air yang mengandung Fe jika melebihi batas, akan berakibat buruk bagi kesehatan. Tujuan penelitian ini adalah untuk menggambarkan biosorben bubuk cangkang bekicot dan untuk menguji presentasi biosorben dalam retensi besi logam substansial (Fe). Dari hasil uji FTIR, dinilai telah terjadi penyesuaian kitin terhadap kitosan. Spektrum kitosan yang diperoleh menunjukkan adanya pita retensi pada bilangan gelombang $3066 \mathrm{~cm}-1$ karena adanya vibrasi memanjang dari gugus - OH. Sedangkan untuk penggambaran menggunakan SEM, ukuran molekul biosorben memiliki

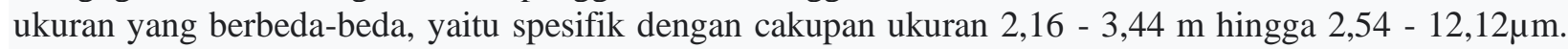
Perkembangan permukaan seperti karang adalah faktor yang paling definitif dalam partisi interaksi retensi logam berat Fe. Perhitungan nilai efektifitas menunjukkan bahwa kecukupan serbuk cangkang bekicot dalam penyerapan logam $\mathrm{Fe} 10 \mathrm{ppm}$ adalah pada massa $20 \mathrm{~g}$ dengan waktu pengadukan 30 menit, yaitu $99,2 \%$.
\end{abstract}

Kata Kunci: biosorben, Bekicot, FTIR, SEM, Fe

\section{Pendahuluan}

Salah satu kebutuhan hidup yang utama bagi masyarakat sekitar adalah air, khususnya air bersih, baik untuk sterilisasi maupun untuk air minum. Dalam memenuhi kebutuhan air, sebagian kecil masyarakat Indonesia menggunakan air tanah sebagai mata air untuk keperluan sehari-hari. Bagaimanapun juga, air tanah tidak boleh langsung dikonsumsi oleh masyarakat setempat karena kandungan racunnya yang besar, misalnya logam berat yang melampaui standar kualitas yang ditetapkan oleh otoritas publik [15]. Konsentrasi zat besi $(\mathrm{Fe})$ yang melimpah dalam air akan menimbulkan berbagai masalah, misalnya masalah khusus seperti pencemaran bak mandi, wastafel, jamban, kerusakan pada pipa yang menyebabkan korosif, dan masalah aktual seperti perubahan warna, bau, dan rasa air seperti halnya secara perlawanan yang dapat mempengaruhi kesejahteraan manusia dan iklim lingkungan[2][6]. Kandungan $\mathrm{Fe}$ dalam air tanah dapat mencapai 10-100 mg/L dengan kadar oksigen yang rendah.

Berdasarkan Pedoman yang ada pada Peraturan Menteri Kesehatan Republik Indonesia Nomor 32 Tahun 2017 tentang Kesejahteraan Ekologis, kadar Fe dalam air yang diperbolehkan untuk disinfeksi dan pencucian umum adalah $1 \mathrm{mg} / \mathrm{l}$. Sementara itu, sesuai Perpres No. 492 Tahun 2010, kadar Fe yang wajar adalah $0,3 \mathrm{mg} / \mathrm{L}$. Oleh karena itu, pengolahan air diharapkan dapat menurunkan kadar Fe dalam air untuk 
memenuhi pedoman kualitas air. Adsorpsi merupakan proses pengolahan air yang efektif yang sering digunakan untuk menghilangkan logam berat [8].

Logam besi $(\mathrm{Fe})$ dibutuhkan oleh tubuh manusia, karena berperan dalam penyusunan hemoglobin. Namun, dalam jumlah yang berlebihan akan sangat mempengaruhi kesehatan manusia, yang merusak saluran pencernaan dan menyebabkan kematian. Selain itu, juga menyebabkan masalah warna, rasa dan aroma dalam air [17]. Untuk menghilangkan logam dalam air dilakukan dengan strategi adsorpsi [1]. Dengan keseluruhan wilayah yang membutuhkan air yang layak untuk dimanfaatkan, para ilmuwan mengarahkan uji coba pengujian penurunan Fe dengan menggunakan teknik adsorpsi. Adsorben yang digunakan adalah biosorben dari bubuk cangkang bekicot. Dan selanjutnya untuk menguji kemampuan biosorben cangkang bekicot dalam menghilangkan logam Fe yang terlarut dalam air. Tujuan penelitian ini adalah untuk menggambarkan biosorben bubuk cangkang bekicot dan untuk menguji kinerja biosorben dalam retensi besi logam substansial $(\mathrm{Fe})$.

\section{Metode Penelitian}

Dalam penelitian ini cangkang bekicot didapat dari bekicot yang masih hidup di area pekarangan rumah warga di daerah Gampong Tualang Tengoh Kota Langsa. Pemeriksaan untuk penelitian ini di Laksanakan pada bulan April hingga Juli 2021. Perlakuan pengujian sampel dilakukan di Laboratorium Teknik Pengujian Kualitas Lingkungan Universitas Syiah Kuala dan Laboratorium Pengujian Jurusan Teknik Kimia Politeknik Negeri Lhokseumawe.

\section{Alat dan Bahan}

Alat-alat dan bahan yang digunakan adalah FTIR, SEM, Oven, AAS, Blender, Timbangan analitik magnetic stirrer, gelas ukur $10 \mathrm{ml}$, kertas saring, beaker glass $100 \mathrm{ml}$, pipet volume, corong, botol sampel, ayakan 100 mesh, cangkang bekicot, aquadest, dan larutan induk Besi $(\mathrm{Fe})$

\section{Prosedur Kerja}

Dalam melakukan penelitian ini peneliti memakai variabel terikat dan variabel bebas dimana variabel terikat berupa konsentrasi besi $(\mathrm{Fe}) 10 \mathrm{mg} / \mathrm{l}$ dan untuk variabel bebasnya berupa variasi massa bubuk cangkang bekicot. Setiap variasi massa bubuk cangkang bekicot yang digunakan adalah $\mathrm{BK}_{1}=5$ gram bubuk cangkang bekicot untuk $100 \mathrm{ml}$ larutan; $\mathrm{BK}_{2}=10$ gram bubuk cangkang bekicot untuk $100 \mathrm{ml}$ larutan; $\mathrm{BK}_{3}=15$ gram bubuk cangkang bekicot untuk $100 \mathrm{ml}$ larutan; $\mathrm{BK}_{4}=20$ gram bubuk cangkang bekicot untuk $100 \mathrm{ml}$ bubuk cangkang bekicot untuk $100 \mathrm{ml}$ larutan. Dalam memvariasikan waktu pencampuran untuk masing-masing contoh perlakuan biosorben adalah diberi variasi 15 menit dan 30 menit.

\section{Persiapan Membuat Bubuk Cangkang Bekicot}

Cangkang bekicot didapat dibersihkan terlebih dahulu dicuci dengan air mengalir, setelah itu cangkang tersebut dipecahkan dan dimasukkan ke dalam oven dengan suhu $90-100^{\circ} \mathrm{C}$ selama 4 jam. Setelah dikeringkan kemudian di blender menggunakan blender listrik dan diayak menggunakan ayakan dengan luas penampang 100 mesh. Serbuk cangkang bekicot diambil sebanyak 5 gram untuk dilakukan pengujian karakterisasi SEM dan FTIR.

\section{Preparasi Larutan standar Fe $10 \mathrm{mg} / \mathrm{L}$}

Preparasi untuk standar $10 \mathrm{mg} / \mathrm{L}$ Fe dibuat menggunakan $1 \mathrm{ml}$ larutan dari Fe 1000 mg/L, kemudian dimasukkan ke dalam gelas ukur $100 \mathrm{ml}$ dan diencerkan dengan menggunakan aquadest sampai tanda batas, sehingga diperoleh larutan $10 \mathrm{mg} / \mathrm{L} \mathrm{Fe}$.

\section{Proses Absorbsi Logam Fe}

Proses absorbsi terhadap logam $\mathrm{Fe}$ dikerjakan setelah membuat larutan standar $\mathrm{Fe}$ dengan konsentrasi $10 \mathrm{mg} / \mathrm{l}$ dari $1000 \mathrm{mg} / \mathrm{l}$ dan mencampurkannya dengan $100 \mathrm{ml}$ air aquadest untuk setiap sampel. Bubuk cangkang bekicot yang ditambahkan pada setiap perlakuan sebanyak 5,10,15 dan 20 gram. Kemudian, bubuk cangkang bekicot ditambahkan ke dalam magnetic stirrer menggunakan pengaduk dengan laju putaran $100 \mathrm{rpm}$ selama 15 menit untuk masing-masing sampel. Sementara itu, untuk tahap kedua, larutan $\mathrm{Fe} 10 \mathrm{ppm}$ dibuat kembali dan divariasikan sesuai dengan perlakuan awal dan di aduk menggunakan magnetic stirrer selama 30 menit untuk masing-masing sampel. Setelah tercampur rata larutan didiamkan selama 24 jam kemudian larutan tersebut disaring dengan menggunakan kertas saring dan diuji menggunakan AAS untuk menentukan kadar logam Fe yang terlarut.

\section{Penentuan efektivitas penyerapan logam}

Seperti yang ditunjukkan oleh ref. [9], produktivitas proses adsorpsi dalam kemampuan menahan logam berat dapat dibatasi dengan membandingkan konsentrasi logam Fe awal dengan konsentrasi logam Fe setelah adsorpsi, dengan persamaan berikut :

$$
E F=\frac{(Y 0-Y F)}{Y 0} \times 100 \%
$$


Dimana $\mathrm{EF}$ adalah degradasi efektifitas, $\mathrm{Y}_{0}$ adalah konsentrasi awal logam $\mathrm{Fe}$ dan $\mathrm{Y}_{\mathrm{F}}$ adalah konsentrasi logam setelah retensi.

\section{Hasil dan Pembahasan}

\section{Karakterisasi Biosorben Cangkang Bekicot dengan Menggunakan FTIR}

Untuk mengetahui gugus fungsi dari kitin maka dilakukan uji karakterisasi biosorben cangkang bekicot dengan menggunakan instrumen Shimadzu Prestige FT-IR 6400 dengan panjang gelombang 4000 $-500 \mathrm{~cm}^{-1}$. Spektrum FTIR yang diperoleh pada biosorben cangkang bekicot diidentifikasi menggunakan fourier infrared spectroscopy (FTIR) dengan range 500 sampai $4000 \mathrm{~cm}^{-1}$. Grafik panjang gelombang spektra inframerah pada biosorben cangkang bekicot ditunjukkan pada Gambar 1.

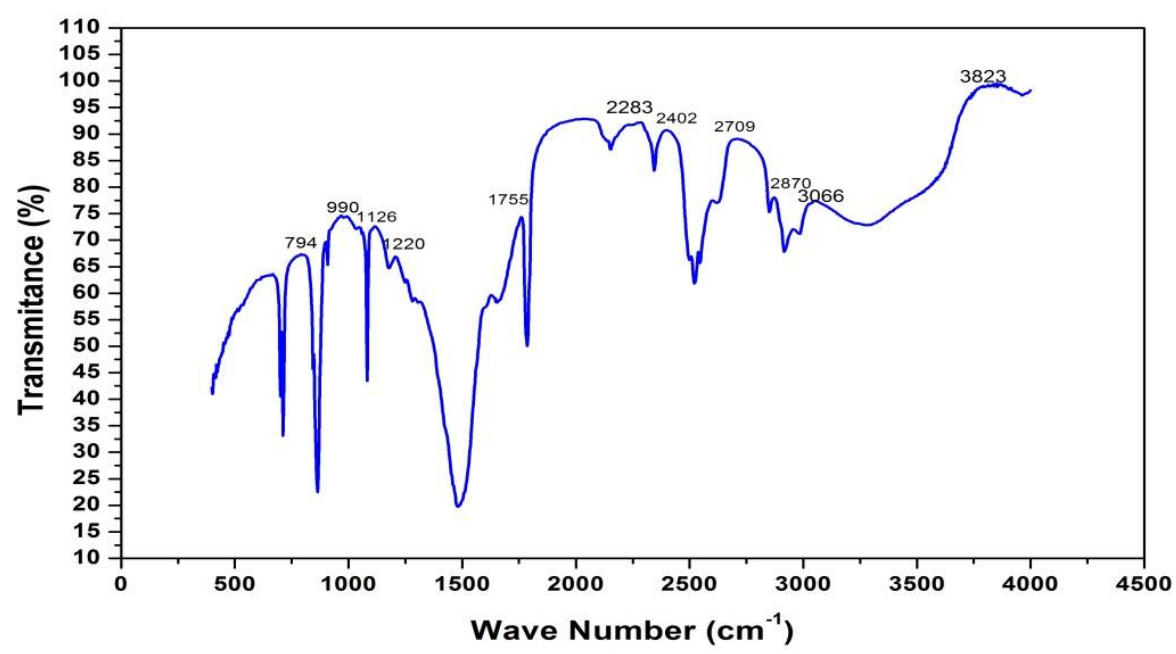

Gambar 1. Analisa gugus fungsi dengan menggunakan FTIR Sumber: Data penelitian, 2021

Proses deasetilasi pada kitin akan terbentuk kitosan. Deasetilasi adalah cara paling umum untuk mengubah gugus asetil (- NHCOCH3) untuk kitin yang akan berubah menjadi gugus amina (- $\mathrm{NH} 2$ ) dalam kitosan dengan perluasan konsentrasi $\mathrm{NaOH}$ yang naik. Respon pada deasetilasi kitin pada dasarnya merupakan respon hidrolisis amida dari 2-asetamida-2-deoksi- $\beta$-(1-4)-D-glukosa) (N-Asetil-DGlukosamin [5]. Dilihat dari spectrum FTIR, dinilai telah terjadi penyesuaian unsur kimia polisakarida kitin menjadi kitosan (Poly d- glucosamine). Spektra kitosan yang diperoleh ditampilkan pada gambar, spektra kitosan menginformasikan adanya pita asimilasi pada bilangan gelombang $3066 \mathrm{~cm}^{-1}$ karena vibrasi memanjang dari rentangan gugus - $\mathrm{OH}$. Lebarnya retensi dan perubahan bilangan gelombang dari gugus $\mathrm{OH}$ adalah disebabkan adanya persilangan dengan pengumpulan gugus $\mathrm{NH}$ dari amina. Asimilasi pada bilangan gelombang $2709 \mathrm{~cm}^{-1}$ menunjukkan gugus $\mathrm{C}-\mathrm{H}$ dari alkana yaitu membuktikan vibrasi memanjang dari gugus - $\mathrm{CH} 2-$.

Kekurangan dari gugus metil (-CH3) yang bertumpu pada amida (- $\mathrm{NHCOCH} 3)$ dapat dilihat dari asimilasi pada bilangan gelombang $2870 \mathrm{~cm}^{-1}$ dan berkumpulnya $\mathrm{C}=\mathrm{O}$ suatu amida (-NHCO-) diketahui dari bermacam-macam kelompok yang terdapat pada bilangan gelombang $1755 \mathrm{~cm}^{-1}$. Ciri serapan kitosan biasa terlihat pada bilangan gelombang $1629 \mathrm{~cm}^{-1}$ menunjukkan vibrasi $\mathrm{N}-\mathrm{H}$ dari amina (- NH2)[12]. Pita retensi pada $1126 \mathrm{~cm}^{-1}$ menunjukkan vibrasi memanjang dari gugus -C-O-. Retensi tajam pada bilangan $794 \mathrm{~cm}^{-1}$ menunjukkan bahwa material mineral pada silika masih terlihat pada kitosan walaupun daya intensitasnya lebih rendah.

\section{Struktur dan Morfologi Biosorben Cangkang Bekicot}

Untuk melihat struktur dan morfologi biosorben dari cangkang bekicot, maka dilakukan pengujian dengan menggunakan Scanning Electron Microscopy (SEM). SEM adalah perangkat keras untuk menguji/melihat desain permukaan contoh dengan amplifikasi hingga $1.000 .000 \mathrm{x}$. Berikut adalah hasil dari pengujian SEM yang dapat kita diilihat pada Gambar 2. 


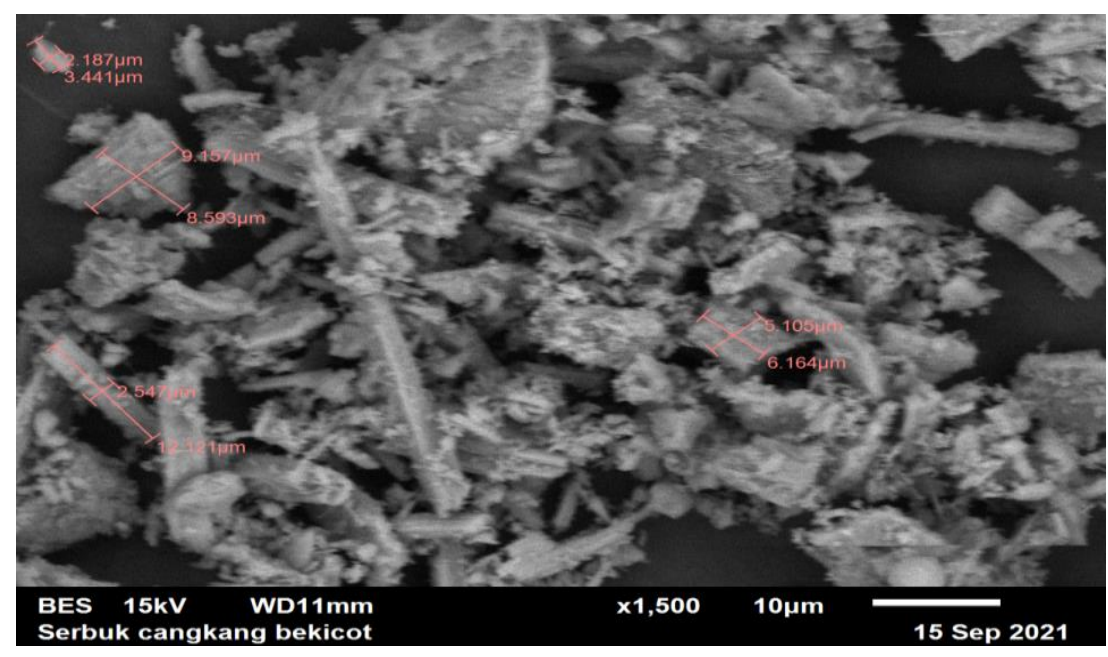

Gambar 2. Struktur dan morfologi biosorben cangkang bekicot Sumber: Data penelitian, 2021

Dari Gambar 2 dapat dilihat ukuran dari partikel biosorben memiliki ragam ukuran yaitu dengan

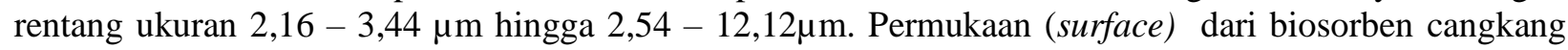
bekicot juga menunjukkan kualitas gambar yang tajam, permukaan halus dan berpori. Desain permukaan permeabel yang lebih halus dan lebih padat akan memiliki pertukaran massa yang lebih besar, sehingga penetrasi udara dari hasil analisa SEM berdasarkan cross section area memperlihatkan bahwa struktur terbentuk seperti karang (sponge). Pembentukan permukaan seperti karang inilah faktor yang paling menentukan pada pemisahan proses ekstraksi logam substansial Fe.

\section{Efektifitas Absorbsi Fe dengan Waktu Pengadukan 15 menit}

Penyerapan logam berat Fe dikerjakan dengan menggunakan berbagai ragam berat dari biosorben cangkang bekicot serta periode pengadukan. Berat dari biosorben cangkang bekicot dan periode pencampuran adalah merupakan salah satu komponen yang dapat mempengaruhi peredaran/daur adsorpsi [9]. Berdasarkan Ref.[3] mengatakan bahwa laju $100 \mathrm{rpm}$ adalah laju aduk yang layak untuk adsorpsi. Hal ini dikarenakan kecepatan yang digunakan oleh putaran pengaduk diatas $100 \mathrm{rpm}$ akan membuat adsorben dan logam terhantar sehingga adsorben tidak akan terikat pada logam substansial. Jika kecepatan putaran pengaduk di bawah $100 \mathrm{rpm}$ yang digunakan maka hampir bisa dipastikan siklus adsorpsi akan lambat. Hal ini di karenakan oleh partikel logam berat akan menghabiskan waktu yang lama untuk dapat masuk terserap oleh adsorben. Pemanfaatan biosorben cangkang bekicot sebagai biosorben dapat menurunkan konsentrasi Fe. Hal tersebut dapat dilihat pada Tabel 1.

Tabel 1. Hasil adsorbsi Fe dengan waktu pengadukan 15 menit

\begin{tabular}{cccc}
\hline $\begin{array}{c}\text { Biosorben Cangkang Bekicot } \\
(\mathrm{gr})\end{array}$ & $\begin{array}{c}\text { Hasil Uji } \\
(\mathrm{mg} / \mathrm{L})\end{array}$ & $\begin{array}{c}\text { Baku Mutu } \\
(\text { PermenLH No. 5 Tahun 2014) }\end{array}$ & $\begin{array}{c}\text { Efektivitas Penyerapan } \\
(\%)\end{array}$ \\
\hline 5 & 0,15 & 5 & $98,5 \%$ \\
10 & 0,14 & 5 & $98,6 \%$ \\
15 & 0,13 & 5 & $98,7 \%$ \\
20 & 0,13 & 5 & $98,7 \%$ \\
\hline
\end{tabular}

Berdasarkan Tabel 1 pada berat 5 gram biosorben cangkang bekicot terjadi penyusutan logam Fe dari konsentrasi $\mathrm{Fe} 10 \mathrm{mg} / \mathrm{L}$ menjadi $0,15 \mathrm{mg} / \mathrm{L}$, kemudian pada berat 10 gram biosorben cangkang bekicot juga terjadi penyusutan logam Fe dari konsentrasi Fe $10 \mathrm{mg} / \mathrm{L}$ menjadi $0,14 \mathrm{mg} / \mathrm{L}$. Selain itu, pada berat 15 dan 20 gram biosorben cangkang bekicot dapat menurunkan konsentrasi hingga menjadi $0,13 \mathrm{mg} / \mathrm{L}$. Menurut ref.[4] dan [13] waktu pencampuran berbanding lurus dengan jumlah partikel yang diasimilasi, dengan alasan semakin lama waktu penggabungan maka semakin banyak partikel logam $\mathrm{Fe}$ yang diasimilasi.

\section{Efektifitas Absorbsi Fe dengan waktu Pengadukan 30 menit}

Hasil penyusutan Fe dengan waktu pengadukan 30 menit dapat dilihat pada Tabel 2. Berdasarkan Tabel 2 terlihat jelas semakin banyaknya pemberian berat gram biosorben cangkang bekicot maka 
semakin rendah fiksasi Fe dalam $10 \mathrm{mg} / \mathrm{l}$. Menurut ref. [18] menerangkan jika sebagai ukuran retensi yang digunakan ditambah maka fiksasi logam yang terkandung akan berkurang.

Tabel 2. Hasil adsorpsi Fe dengan waktu pengadukan 30 menit.

\begin{tabular}{cccc}
\hline $\begin{array}{c}\text { Biosorben Cangkang Bekicot } \\
(\mathrm{gr})\end{array}$ & $\begin{array}{c}\text { Hasil Uji } \\
(\mathrm{mg} / \mathrm{L})\end{array}$ & $\begin{array}{c}\text { Baku Mutu } \\
(\text { PermenLH No. 5 Tahun 2014) }\end{array}$ & $\begin{array}{c}\text { Efektivitas Penyerapan } \\
(\%)\end{array}$ \\
\hline 5 & 0,12 & 5 & $98,8 \%$ \\
10 & 0,11 & 5 & $98,9 \%$ \\
15 & 0,09 & 5 & $99,1 \%$ \\
20 & 0,08 & 5 & $99,2 \%$ \\
\hline
\end{tabular}

Pada biosorben cangkang bekicot dengan berat 5 gram konsentrasi $\mathrm{Fe} 10 \mathrm{mg} / \mathrm{l}$ terjadi penyusutan menjadi $0,12 \mathrm{mg} / \mathrm{l}$. Pada biosorben cangkang bekicot dengan berat 10 gram konsentrasi $\mathrm{Fe} 10 \mathrm{mg} / \mathrm{l}$ turun sebanyak $0,11 \mathrm{mg} / \mathrm{l}$. Sedangkan pada berat 15 gram biosorben cangkang bekicot konsentrasi Fe $10 \mathrm{mg} / \mathrm{l}$ terjadi penyusutan sebanyak $0,09 \mathrm{mg} / \mathrm{l}$, dan pada berat 20 gram biosorben cangkang bekicot dapat menurunkan konsentrasi Fe $10 \mathrm{mg} / \mathrm{l}$ menjadi $0,08 \mathrm{mg} / \mathrm{l}$ yaitu dengan kadar efektivitas penyerapan logam berat Fe sebesar 99\%. Seperti yang ditunjukkan oleh ref. [7] waktu pengadukan secara relatif berbanding lurus dengan jumlah partikel yang diasimilasi, dengan alasan bahwa semakin lama waktu pengadukan maka semakin banyak partikel logam Fe yang dikonsumsi.

\section{Kesimpulan}

Hasil Penelitian menunjukkan karakteristik dari gugus fungsi berdasarkan spectrum FTIR yang didapat diperkirakan bahwa telah terjadi penyesuaian unsur kimia polisakarida kitin menjadi kitosan (Poly d- glucosamine) dan spektra kitosan menginformasikan adanya pita asimilasi pada bilangan gelombang $3066 \mathrm{~cm}^{-1}$ karena vibrasi memanjang dari rentangan gugus - OH. Sedangkan untuk karakterisasi menggunakan SEM di dapat ukuran partikel biosorben memiliki ragam ukuran yang berbeda-beda yaitu dengan rentang ukuran 2.16 - $3.44 \mu \mathrm{m}$ hingga $2.54-12.12 \mu \mathrm{m}$. Desain permukaan permeable yang lebih halus dan dan lebih padat akan memiliki pertukaran massa yang lebih besar, sehingga penetrasi udara dari hasil analisa SEM berdasarkan cross section area memperlihatkan bahwa struktur terbentuk seperti karang (sponge). Pembentukan permukaan seperti karang inilah faktor yang paling menentukan pada pemisahan proses penyerapan logam berat Fe. Perhitungan nilai efektifitas diperoleh hasil efektifitas bubuk cangkang bekicot dalam menyerap logam Fe $10 \mathrm{mg} / \mathrm{l}$ adalah pada biosorben cangkang bekicot dengan berat 20 gram dan waktu pencampuran 30 menit yaitu sebanyak $99,2 \%$.

\section{Referensi}

[1] Agustina. S dan Kurniasih. Y, "Pembuatan Kitosan Dari Cangkang Udang dan Aplikasinya Sebagai Absorben Untuk Menurunkan Kadar Logam CU," IKIP, Mataram 2013.

[2] Febrina. L, Ayuna. A, "Studi Penurunan Kadar Besi (Fe) dan Mangan (Mn) Dalam AIr Tanah Menggunakan Saringan Kermaik," Jurnal Teknik Teknologi, Volume 7 No. 1, 2015.

[3] I. Syauqiah, M. Amalia, dan A. H Kartini, " Analisis Variasi Waktu Kecepatan Pengaduk pada Proses Adsorpsi Limbah Logam Berat dengan Arang Aktif, " Jurnal Info Teknik, (11), 2011.

[4] Kurniawan. E, Asril. A, Ningsih. J.R, "Sintesis Karakterisasi Kalsium Oksida dari Limbah Cangkang Bekicot (Achatina fulica)," Jurnal J. Chem, (50-54) 2019.

[5] Kusumaningsih. T, Masykur. A, Arief. U, " Pembuatan Kitosan dari Kitin Cangkang Bekicot (Achatina fulica)," Jurnal Biofarmasi 2, (64-68), 2004.

[6] Liu Y, Feng C, Sheng Y, Dong S, Chen N and Hao C 2018 Ecotoxicol. Environ. Saf. $166437-445$

[7] Manalu. N. Kresentia. P. Dimas, Widodo, dan L. Urip, "Adsorpsi Logam Fe Dalam Minyak Nilam Menggunakan Kitosan Sisik Ikan," Jurnal Teknik Kimia, Volume 14 No. 01, 2019.

[8] Mandasari I and Purnomo A 2016 J. Tek. ITS 5 1-6

[9] Mauriza. R, Yahya. H, Ashari. T.M, "Uji Efektivitas Cangkang Keong Mas (Pomacea canaliculata L.) sebagai Biosorben Dalam Menyerap Logam Berat Merkuri (Hg)," Jurnal Serambi Engineering, (1332-1337), Volume V, No. 4, 2020.

[10] Putri, "Pembuatan Kitosan dari Cangkang Keong Mas Untuk Adsorben Fe pada Air Sumur," Skripsi, Surakan Fakultas Teknik Prodi D-III Teknik Kimia 2014.

[11] Prihatman. K, "Budidaya Bekicot (Achatina spp), Jakarta, Budidaya Peternakan, Hal. 32, 2000.

[12] Ridwanto, Utama. F.A, Syahputra, R.A, "Pemanfaatan Limbah Cangkang Bekicot (Acathina fulica) Sebagai Bahan Baku Pembuatan Kitosan", Jurnal Saintika, Volume 16 (2): 43-48, 2016 
[13] Santoso. A.I, dan Putro. D.S, "Efektivitas Cangkang Hama Bekicot (Achantina fulica) Sebagai Adsorben Untuk Meningkatkan Kualitas Air Sungai Kahayan," Jurnal Serambi Engineering, (14151420), Volume V, No. 4, 2020.

[14] Supriyantini. E, dan Endrawati. H, "Kandungan Logam Berat Besi (Fe) Pada Air, Sedimen dan Kerang Hijau (Perna viridis) di Perairan Tanjung Emas Semarang", Jurnal Kelautan Tropis, Volume $18,(38-45) 2015$.

[15] S Maliki, C M Rosnelly, A Adisalamun, H Husin, N Bilqis, "Removal of Fe (II) in groundwater using rice husk-sourced biosorbent in continuous column adsorption", J. Phy: Conf. Ser.1402 055007, 2019.

[16] S.TjuTju, "Air Sebagai Sumber Kehidupan," Oseana, Volume 23 No. 3 (17-25). LIPI 2003.

[17] Valentine, D.A, Aprilia. S, Fauzi, "Sintesis Membran Kitosan-Silika Abu Sekam Padi Untuk Penurunan Logam Berat Cu dengan Proses Ultrafiltrasi," Jurnal Serambi Engineering, Volume 4, 2019.

[18] Victor. S, Andhika. B, Syauqiah. I, " Pemanfaatan Kitosan Dari Limbah Cangkang Bekicot (Achatina fulica) Sebagai Adsorben Logam Berat Seng (Zn)," Jurnal Konversi, Volume 5 No. 1, 2016. 